\title{
Diet specialization in an insular population of coastal Peregrine Falcons
}

\author{
Luke J. Sutton ${ }^{1,2^{*}}$ \& Sebastian W. Loram ${ }^{3}$
}

${ }^{1}$ School of Biological and Marine Sciences, University of Plymouth, Drake Circus, Plymouth, Devon PL4 8AA UK.

${ }^{2}$ The Peregrine Fund, 5668 West Flying Hawk Lane, Boise, Idaho 83709 USA.

${ }^{3}$ Independent Researcher, Galmpton, Devon, UK.

${ }^{*}$ Corresponding author: Isutton@peregrinefund.org

Running head: Diet specialization in Peregrine Falcons

\section{Abstract}

Individual diet specialization is known to occur in populations of generalist predators, where specific individuals develop specialist feeding strategies. Diet specialization has been reported in many raptor species, and it may be an important driver of intraspecific population structure. Here, we quantify the diet of five breeding pairs of Peregrine Falcons Falco peregrinus from an offshore island determined from prey remains collected over four breeding seasons. Three prey species accounted for $69.8 \%$ of total prey frequency, with Manx Shearwater Puffinus puffinus the primary prey accounting for $47.3 \%$ by frequency and $40.8 \%$ by biomass. Herring Gull Larus argentatus was the second most important prey species by frequency $(13.8 \%)$ and biomass $(29.8 \%$ ) followed by Domestic Pigeon Columba livia (frequency $=8.7 \%$, biomass $=7.0 \%$ ). Predation frequency on specific prey groups varied substantially between breeding pairs and months. Two pairs specialized on Manx Shearwater, one pair specialized on Herring Gull and Manx Shearwater, with the remaining two 
pairs having a relatively generalist diet of Manx Shearwaters, Domestic Pigeon and small passerines. Predation on Manx Shearwaters increased throughout the breeding season with a peak in total diet frequency of $63.8 \%$ in July, with a concurrent decrease in Herring Gull predation frequency. Higher percentage of Manx Shearwater in the diet was able to explain $87 \%$ of the variation in a narrower dietary breadth for the Peregrine pairs. Our results suggest individual diet specialization may be important for understanding population density in insular raptor populations.

Key words: diet breadth, Falco peregrinus, individual diet specialization, Peregrine Falcon, raptor diet, resource partitioning

\section{Introduction}

Ecological specialization is a key concept in ecology and evolutionary biology (Bolnick et al. 2003, Araujo et al. 2011), with individual diet specialization (IDS) a potential mechanism promoting coexistence between individuals through specialized use of food resources (Schoener 1974, Wiens 1984). Populations of diet generalist species are often comprised of a subset of diet specialized individuals (PaganiNunez et al. 2016). This may reduce resource-use overlap because specialized individuals utilize a narrower range of resources than conspecific competitors. IDS is expected to be common amongst species occupying higher trophic levels, where intraspecific competition for resources is expected to be high (Navarro-Lopez et al. 2014). Recently, studies of IDS within raptor populations have established this behaviour may be common in this bird group (e.g., Constantini et al. 2005, Whitfield et al. 2009, Navarro-Lopez et al. 2014, Terraube et al. 2014). Specialized individuals 
within raptor populations may have higher reproductive success than generalists (Dawson et al. 2011), though that assertion may not always apply (Whitfield et al. 2009). Therefore, understanding IDS is important because of its potential to regulate intraspecific population dynamics and breeding success (Bolnick et al. 2003, Ceia \& Ramos 2015).

The Peregrine Falcon Falco peregrinus (hereafter 'Peregrine') is a widely distributed raptor with a global range, and considered a diet generalist, feeding on a broad range of other bird species (White et al. 2013). Though IDS has been described in several Peregrine populations from North and South America (Beebe 1960, Verlade 1993, Castellanos et al. 2006, Garcia et al. 2014), and anecdotally from the British Isles (Ratcliffe 1993), quantitative data is lacking from much of the Peregrine's global range. In the British Isles, the Peregrine has a largely generalist diet (e.g., Dixon 2005, Sutton 2015a), with Domestic Pigeon Columba livia the primary prey (Ratcliffe 1993; Dixon et al. 2018). The British Isles has many small offshore islands off its western seaboard, some of which have dense sub-populations of breeding Peregrines relative to their area (Ratcliffe 1993; Sutton 2015b, Sutton 2016). Ratcliffe (1993) suggested that the population density of these island Peregrines may be driven by seabird abundance, which are likely to comprise the main food source for this insular Peregrine sub-populations.

Recent dietary assessments from Lundy, an island in the Bristol Channel between England and Wales, indicate that seabirds, including Manx Shearwater Puffinus puffinus and Herring Gull Larus argentatus, are the primary food source for the resident Peregrines (Sutton 2016; Sutton et al. 2017). Lundy was historically one of many important seabird colonies lying off the south west coast of the British Isles (Brown et al. 2011). Since the 1900's seabird populations on the island have 
declined due to predation from invasive predators and human over-harvesting. After the eradication of Black Rattus rattus and Brown Rats $R$. norvegicus on the island in 2006 and formal legal protection, there has been an increase in breeding seabirds, in particular Manx Shearwater (Booker \& Price 2014). Lundy also has a high breeding density of Peregrines, with five territorial pairs resident from 2002 to the present (Sutton 2016). The factors influencing this high breeding density are complex and not fully understood. However, one contributory factor may be diet specialization, allowing reduced competition for food resources, possibly enabling more pairs to breed in close proximity. Here, we assess foraging behaviour and diet specialization in this insular Peregrine population during the breeding season between the years 2014 and 2017. We aim to: (1) quantify diet composition and spatio-temporal patterns of predation, and (2) determine the level of individual diet specialization amongst the five resident breeding pairs.

\section{Methods}

\section{Study area}

Lundy $\left(51^{\circ} 11^{\prime} \mathrm{N}, 04^{\circ} 40^{\prime} \mathrm{W}\right)$ is a small offshore island located in the Bristol Channel, England, $18 \mathrm{~km}$ from the nearest mainland point in the administrative county of Devon. The island is approximately $5-\mathrm{km}$ long by $1-\mathrm{km}$ wide, with $13-\mathrm{km}$ of mainly granite sea cliffs. Elevation on the island plateau ranges from 80-143 m/asl, covering an area of approximately $445 \mathrm{ha}$. Two-thirds of the island plateau is comprised of unimproved grassland, moorland and maritime heath, dominated by Common Heather Calluna vulgaris. The southern third of the island supports a small tourist and farming community where the dominant land use is semi-improved and improved grassland. 


\section{Data collection}

We collected prey samples on a monthly basis between April and August 2014-2017 from five territorial breeding pairs. We followed a pre-determined circuit of the island recording food items from prey remains (including feathers, bones, and carcasses) left after feeding (Marti et al. 2007). We conducted systematic transect searches within territories, checking regular plucking areas along cliffs and slopes adjacent to nest cliffs. Prey remains were assigned to a territory if located within a 400-m radius of the nest cliff. This distance was determined as the minimum cross-over radius between territories to prevent recording outside of a known territory. We defined territories on cardinal points of the compass as: L1/NE (North-East); L2/E (East); L3/S (South); L4/SW (South-West); L5/W (West). Any remains found outside the 400- $\mathrm{m}$ radius from nest cliffs were assigned as random events and not used in the spatial analyses.

Prey remains were removed for identification and the location recorded with a handheld Global Positioning System (GPS) device to prevent double recording on subsequent visits. Remains observed on inaccessible feeding areas were recorded using a Digital Single Lens Reflex (DSLR) camera for later analysis and the location recorded indirectly using Google Earth (https://earth.google.com/web/) software. We identified prey species from Brown et al. (2003) and previous experience (Sutton 2015a, 2016; Sutton et al. 2017). Avian prey remains from Peregrines are readily identified. On carcasses the breast is ruptured with distinct notches in the breastbone from the Peregrines' beak when feeding (Bang \& Dahlstrom 2011). Plucked feathers will often be found concentrated in a pile surrounding the carcass indicating a kill, distinct from gull feeding remains (Corkhill 1973). Any raptor kills 
recorded during the breeding period were assumed to be from Peregrines as they are the only resident breeding raptor on Lundy (Davis \& Jones 2007).

\section{Statistical analysis}

We divided prey items into nine prey groups (Auks, Corvids, Ducks/Waders, Gulls, spatial and temporal variation in total prey frequency between territories and months using Fisher's Exact test. We calculated dietary niche breadth $(B)$ on the sum total of all prey items using the formula of Levins (Krebs 1999),

$$
B=1 / \sum p_{i}^{2}
$$

where $p_{\mathrm{i}}$, represents the proportion of the diet contributed by the ith taxon. Niche breadth was then standardized $\left(B_{A}\right)$ for easier interpretation following Hurlbert (1978),

$$
B_{A}=\frac{B-1}{n-1}
$$

Values for this index range on a scale of 0.0 to 1.0 with lower values towards zero indicating narrower dietary breadth and higher values towards one indicating broader diet breadth. We used linear regression to model the relationship between prey weight and log-transformed frequency of predation, and to model the relationship between percentages of Manx Shearwater with total dietary breadth from each territorial pair. All statistical analyses were performed in R (v3.5.1, R Core Team 2018). 


\section{Results}

147

Table 1. Percent frequency of predation by prey weight groups

\begin{tabular}{lc}
\hline Prey weight group $(\mathrm{g})$ & Frequency $(\%)$ \\
\hline$<50$ & 11.5 \\
$51-250$ & 3.7 \\
$251-500$ & 62.1 \\
$501-1000$ & 18.9 \\
$>1000$ & 3.9 \\
\hline Total & 100.0
\end{tabular}




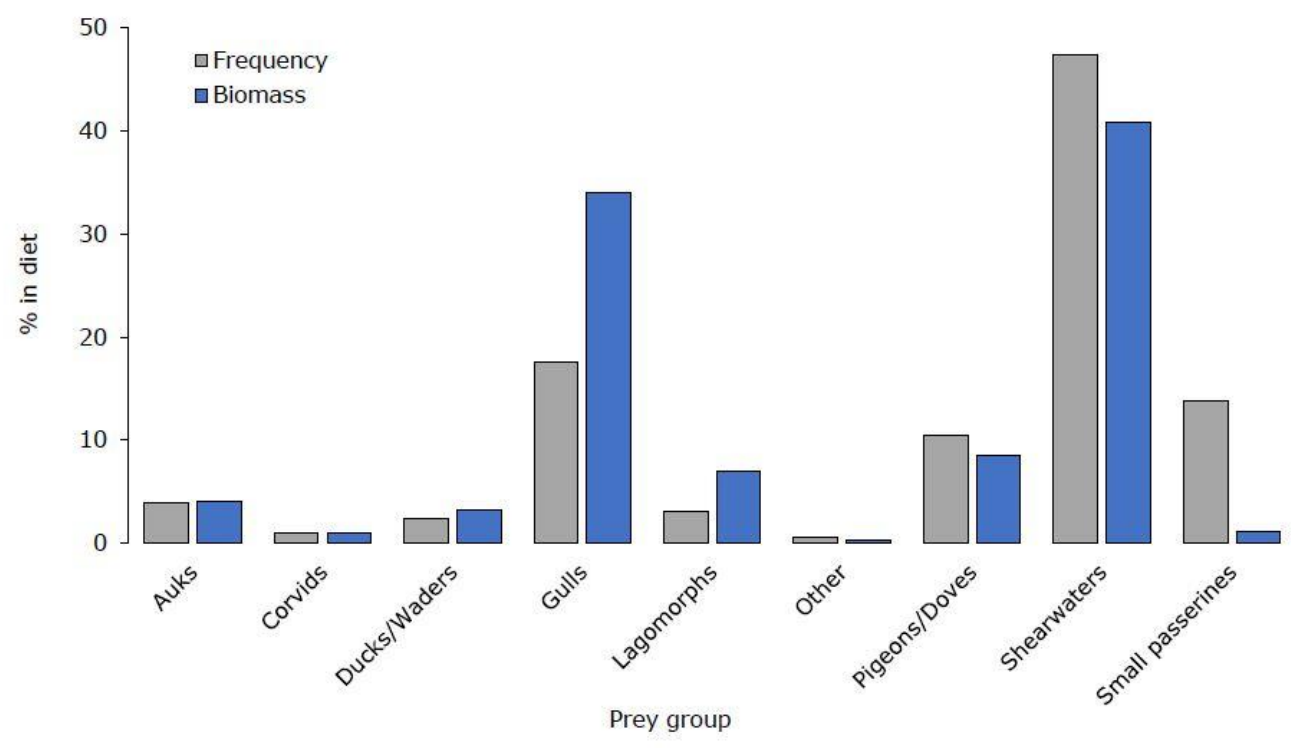

Figure 1. Prey groups by total frequency and biomass (\%) predated by Peregrine Falcons breeding on Lundy from April-August 2014-2017.

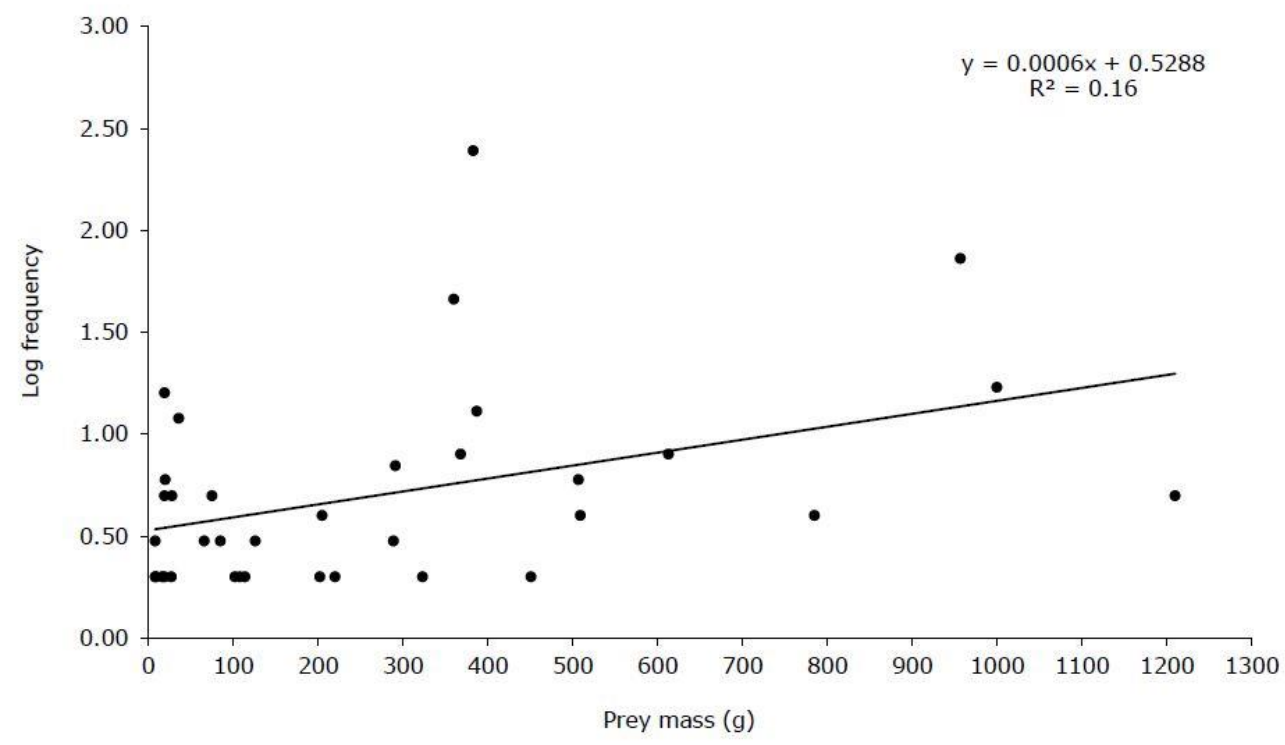

170 Figure 2. Predation frequency by mass of individual prey species taken by Peregrine Falcons breeding on Lundy from April-August 2014-2017. Unit mass (g) taken from BTO (2016). 
172 Prey group diet composition varied substantially between nest territories (Fisher's

173 Exact $=p<0.001$, Fig. 3). Peregrine pairs in territories L1/NE and L4/SW had a high

174 proportion of Shearwaters indicating a specialized diet $(\mathrm{L} 1 / \mathrm{NE}=53.7 \%$, L4/SW $=$

$17562.6 \%$ ). Pairs in territories L2/E and L3/S showed a generalist diet of

176 Pigeons/Doves, Shearwaters and Small Passerines (Fig. 3). The pair in territory

177 L5/W were diet specialists of both Shearwaters (47.1\%) and Gulls (35.0\%), with the

178 pair in territory L4/SW also regularly taking Gulls, albeit less frequently (20.9\%).

179 Frequency of prey group predation also varied substantially over the five-month

180 (April-August) sampling period (Fisher's Exact $=p<0.001$, Fig. 4). Relatively equal

181 numbers of Gulls, Shearwaters and Small Passerines were predated in April, with a

182 steady increase in total frequency of Shearwater predation from May onwards,

183 peaking in July at $63.8 \%$. Conversely, as frequency of Shearwater prey group

184 predation increased, Gull prey group predation frequency dropped to a low of $6.3 \%$

185 by July, before a marked increase in August (26.3\%). 


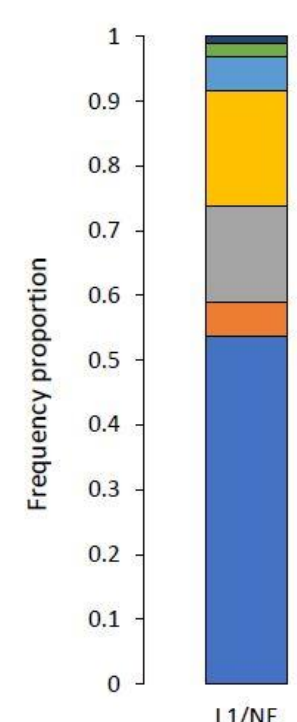

L1/NE

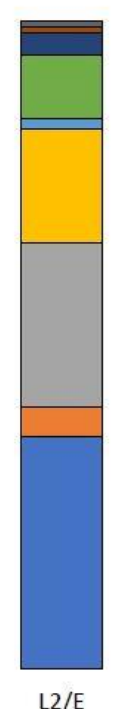

L2/E

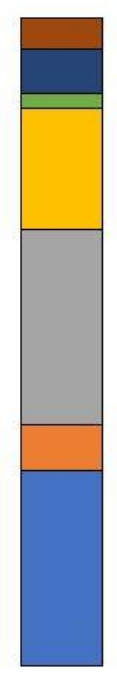

$\mathrm{L} 3 / \mathrm{S}$

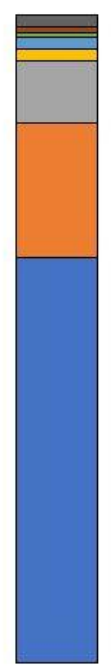

L4/SW

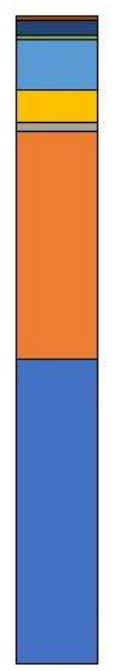

L5/W $\square$ Shearwaters

$\square$ Gulls

口Small passerines

$\square$ Pigeons/Doves

$\square$ Auks

$\square$ Lagomorphs

口Ducks/Waders

$\square$ Corvids

Other

Breeding territory

Figure 3. Spatial variation between nest territories in frequency of prey groups predated by Peregrine
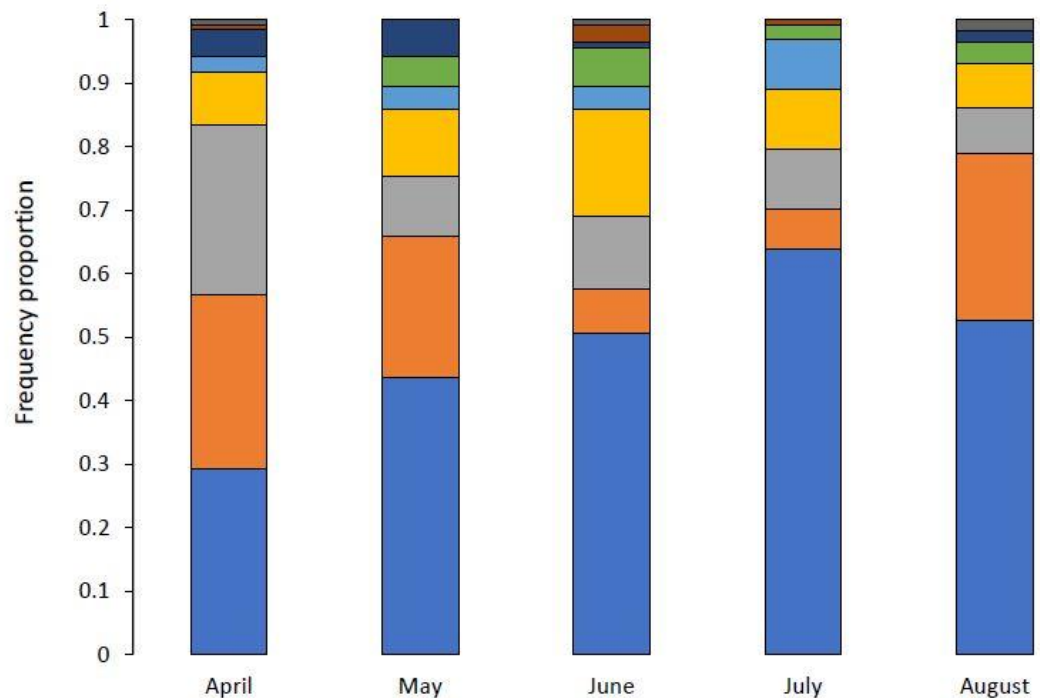

$\square$ Shearwaters

\section{$\square$ Gulls}

$\square$ Small passerines

$\square$ Pigeons/Doves

口Auks

口Lagomorphs

$\square$ Ducks/Waders

口Corvids

$\square$ Other

Month

Figure 4. Temporal variation by month in frequency of prey groups predated by Peregrine Falcons breeding on Lundy from April-August 2014-2017. 
193

The pair in territory L4/SW had the narrowest diet breadth and were the most specialized in terms of diet $\left(B_{A}=0.073\right)$, followed by the pairs in territory $\operatorname{L} 1 / \mathrm{NE}\left(B_{A}=\right.$ $0.116)$ and $\mathrm{L} 5 \mathrm{WW}\left(B_{A}=0.119\right)$ both with similar narrow diet breadth. Pairs at the remaining territories had relatively broader niche breadth and a more generalist diet (L2/E: $\left.B_{A}=0.222 ; \mathrm{L} 3 / \mathrm{S}: B_{A}=0.346\right)$. There was a strong inverse relationship between narrow dietary breadth and high percentage of Manx Shearwater in the diet of the territorial pairs (Fig. 5), with the percentage of Manx Shearwater in the diet explaining $87 \%$ of the variation in dietary breadth $\left(F_{1,3}=20.2, R^{2}=0.87, p=0.02\right)$.

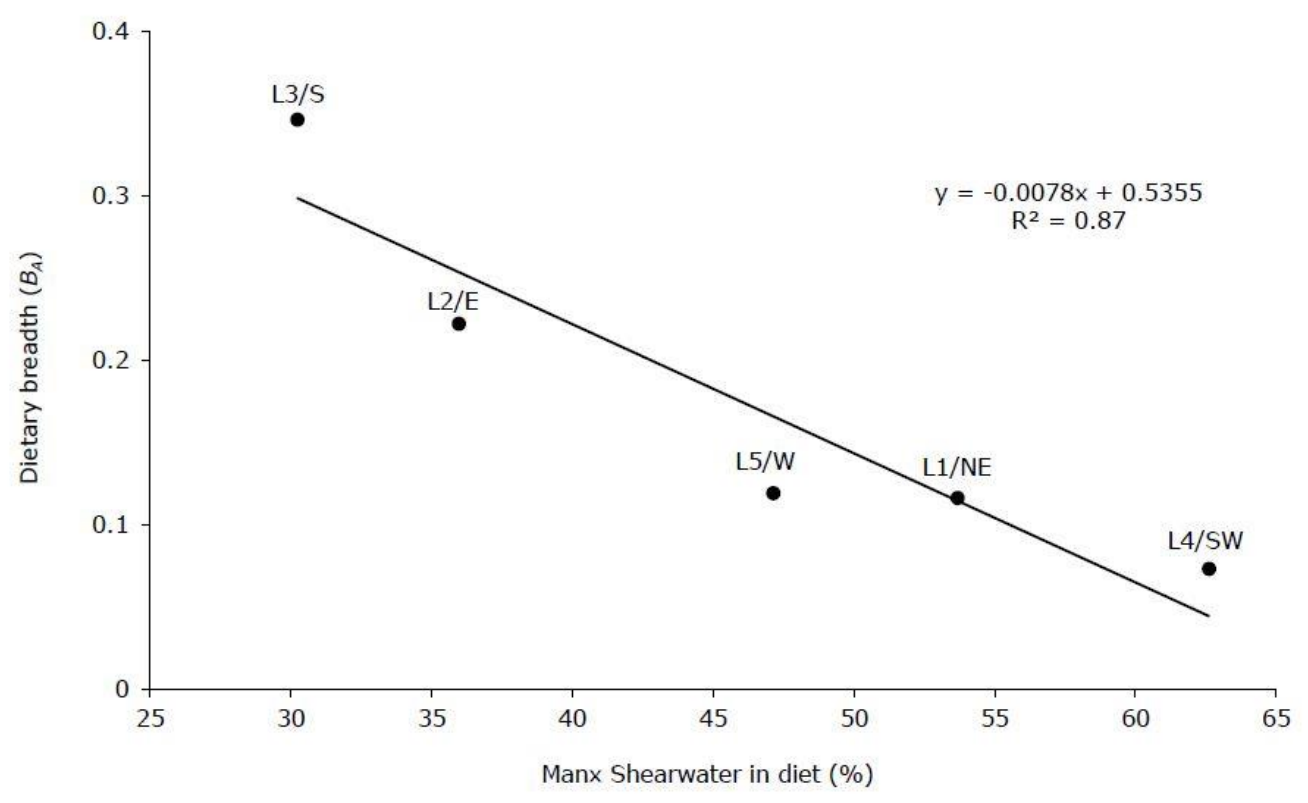

Figure 5. The relationship between Manx Shearwaters in total diet (\%) and dietary breadth $\left(B_{A}\right)$. Each black point represents a breeding pair of Peregrine Falcons. 


\section{Discussion}

208

Our results demonstrate that specific breeding pairs of Peregrines on Lundy have a specialized diet, with Manx Shearwater the principal prey. This followed our general expectations given the marine location, though the finding that large prey such as Herring Gull and Rabbit were important food sources was unexpected. Prey mass was able to explain $16 \%$ of the variation in predation frequency, with prey between 251-500 $\mathrm{g}$ the most common prey group. There was noticeable variation in spatial and temporal predation frequency, with the number of Manx Shearwater predated increasing substantially during June and July at three specific nest territories. Even so, all breeding pairs had narrow dietary breadth, with just three prey species accounting for $\sim 70 \%$ of all prey taken. The trend of regular predation by Peregrines on specific prey types may have important implications for understanding IDS and its potential influence on insular raptor population structure.

Our results show the importance of Manx Shearwater in the diet of Peregrines breeding on Lundy. They were the most common prey species and group by both frequency and biomass (Fig. 1; Table S1). This finding is similar to other studies on insular Peregrine populations on offshore islands along the Pacific north west coast of North America. Here, the resident Peregrine sub-species F.p. pealei, has adapted to local prey availability, and specialises on feeding almost exclusively on Ancient Murrelets Synthliboramphus antiquus (Nelson 1990). Peregrine productivity and the number of breeding pairs fluctuates in accordance with seabird breeding density (Nelson \& Myres, 1976; Nelson 2004). Understanding whether the number and distribution of the Manx Shearwater population on Lundy directly affects Peregrine breeding success is a key question to be determined from future research. Our results show that Shearwater predation frequency increases during June and July 
when food demand is highest from nestlings. Though there is no evidence that Peregrine breeding density is linked to the increase in the Manx Shearwater population, this abundant food supply could facilitate an increase in productivity for certain pairs in this Peregrine sub-population.

The mechanisms driving IDS in this insular Peregrine population are still unclear. Peregrines are highly territorial thus individuals could be restricted by territoriality between nesting pairs, limiting access to certain food resources (Ratcliffe 1993). Patchy habitats could be a key driver by providing different prey types to specific individuals, which then increase their foraging success and handling time by specialization (Sargeant 2007; Terraube et al. 2014). However, with such a dense population of Peregrines in a small area, intense intra-specific competition between breeding pairs for territory space, and therefore food, may be the strongest factor. Further research on home range size and foraging distances would be required to assess how Peregrines on Lundy defend territories and utilise habitats for these resources. Establishing if any broad-scale patterns of diet specialization exist for insular Peregrine populations across the British Isles may help inform conservation management for offshore islands in the region. Many of these islands hold globally important populations of seabirds which are often the main prey of Peregrines (Ratcliffe 1993). Therefore, considered management of seabird populations could indirectly benefit the predators that utilise them as a food resource.

Even though determining dietary habits from feeding remains is an established indirect method of assessing raptor diet (Marti et al. 2007), we recognise that indirect methods may over-represent large or brightly coloured prey species compared to small or darker prey remains that may go undetected (Ratcliffe 1993). Despite our thorough systematic sampling, we assume that some feeding areas were missed or 
inaccessible. Prey was observed being brought into nest ledges or feeding areas at territories L1/NE and L3/E that were inaccessible and out of sight. Thus, future dietary assessments of breeding season diet would benefit from direct methods using stable isotope analysis from tissue sampling of nestlings (Denhard et al. 2016; Horswill et al. 2016). It follows that the results presented here are only representative of what prey remains were observed and accessible.

Density compensation theory postulates that island species tend towards a generalist foraging strategy once released from competition with other species (Wright 1980). However, in some species, such as the Peregrine, this may be reversed and individuals within a given population may become diet specialists.

Determining trophic relationships and relating those results to population dynamics in both predator and prey species is essential (Paine et al. 1990; Hipfner et al. 2011). This may establish how populations of avian apex predators are regulated on islands such as Lundy and how they interact in ecological community structures.

\section{Acknowledgements}

LJS thanks the Birds of Lundy Fund, the Hawk and Owl Trust and the Lundy Field Society for providing financial assistance to conduct this research. We thank Dean Jones (Lundy Warden) who assisted with fieldwork and logistics.

\section{References}

Araujo, M.S., Bolnick, D.I. \& Layman, C.A. 2011. The ecological causes of individual specialization. Ecology Letters 14: 948-958.

Bang, P. \& Dahlstrom, P. 2011. Animal tracks and signs. OUP, Oxford.

Bolnick, D.I., Svanback, R., Fordyce, J.A., Yang, L.H., Davis, J.M., Hulsey, C.D. \& Forister, M.L. 2003. The ecology of individuals: Incidence and implications of individual specialization. The American Naturalist 161: 1-28. 
Beebe, F. L. 1960. The marine Peregrines of the Northwest Pacific coast. The Condor 62: 145-189.

Booker, H. \& Price, D. 2014. Manx Shearwater recovery on Lundy: Population and distribution change from 2001 to 2013 . Journal of the Lundy Field Society 4:105-116.

Brown, A., Price, D., Slader, P., Booker, H., Lock, L. \& Deveney, D. 2011. Seabirds on Lundy: their current status, recent history and prospects for the restoration of a once-important bird area. British Birds 104: 139-158.

Brown, R., Ferguson, J., Lawrence, M. \& Lees, D. 2003. Tracks and Signs of the Birds of Britain and Europe, $2^{\text {nd }}$ Ed. Christopher Helm, London.

British Trust for Ornithology. 2016. http://www.bto.org [online]. http://www.bto.org/about-birds/birdfacts (Accessed 25 August 2020).

Castellanos, A., Arguelles, C., Salinas, F., Rodriguez, A., \& Ortega-Rubio, A. 2006. Diet of breeding peregrine falcons at a coastal lagoon, Baja California Sur, Mexico. Journal of Raptor Research 40: 241-244.

Ceia, F.R. \& Ramos, J.A. 2015. Individual specialization in the foraging and feeding strategies of seabirds: a review. Marine Biology 162: 1923-1938.

Constantini, D., Casagrande, S., Di Lieto, G., Fanfani, A. \& Dell'Omo, G. 2005. Consistent differences in feeding habits between neighbouring breeding kestrels. Behaviour 142: 1409-1421.

Corkhill, P. 1973. Manx Shearwaters on Skomer: population and mortality due to gull predation. British Birds 66: 136-143.

Davis, T.J. \& Jones, T.A. 2007. The Birds of Lundy. Devon Birdwatching \& Preservation Society and Lundy Field Society. Harpers Mill, Devon, UK.

Dawson, R.D., Mossop, D.H. \& Boukall, B. 2011. Prey use and selection in relation to reproduction by Peregrine Falcons breeding along the Yukon River, Canada. Journal of Raptor Research 45: 27-37.

Dehnhard, N., Eens, M., Sturaro, N., Lepoint, G., Demongin, L., Quillfeldt, P. \& Poisbleau, M. 2016. Is individual consistency in body mass and reproductive 
decisions linked to individual specialization in foraging behaviour in a long-lived seabird? Ecology and Evolution. DOI: 10.1002/ece3.2213.

Dixon, A. 2005. The prey of Peregrines Falco peregrinus at breeding territories in Northumberland. Trans. Nat. Hist. Soc. Northumbria 64: 111-120.

Dixon, A., Richards, C. \& King, A. 2018. Diet of Peregrine Falcons (Falco peregrinus) in relation to temporal and spatial variation in racing pigeon availability in Wales. Ornis Hungarica 26: 188-200.

Garcia, G.O., Susana Bo, M. \& Yorio, P. 2014. Prey composition of peregrine falcons (Falco peregrinus) preying upon a mixed-species seabird colony in Argentine Patagonia. Ornitologia Neotropical 25: 1-5.

Hipfner, J.M., Morrison, K.W. \& Darvill, R. 2011. Peregrine Falcons enable two species of colonial seabirds to breed successfully by excluding other aerial predators. Waterbirds 34: 82-88.

Horswill, C., Matthiopoulos, J., Ratcliffe, N., Green, J.A., Trathan, P.N., McGill, R.A.R., Phillips, R.A. \& O'Connell, T.C. 2016. Drivers of intrapopulation variation in resource use in a generalist predator, the macaroni penguin. Marine Ecology Progress Series 548: 233-247.

Hurlbert, S.H. (1978). The measurement of niche overlap and some relatives. Ecology 59: 67-77.

Krebs, C.J. 1999. Ecological Methodology, $2^{\text {nd }}$ Ed. Benjamin-Cummings, Menlo Park, California.

Marti, C.D., Bechard, M. \& Jaksic, F.M. 2007. Food habits. In: Bird, D.M., Bildstein, K.L., Barber, D.R. \& Zimmerman, A. (eds). Raptor research and management techniques. Raptor Research Foundation, Hancock House, Canada. p. 129151.

Navarro-Lopez, J., Vergara, P. \& Fargallo, J.A. 2014. Trophic niche width, offspring condition and immunity in a raptor species. Oecologia 174:1215-1224.

Nelson, R.W. 1990. Status of the Peregrine Falcon Falco peregrinus pealei, on Langara Island, Queen charlotte Islands, British Columbia, 1968-1989. The Canadian Field-Naturalist 104: 193-199. 
Nelson, R.W. 2004. The 1995 Peregrine Falcon survey on Langara Island. The 1995 Peregrine Falcon survey in Canada. Number 110, Canadian Wildlife Service.

Nelson, R.W. \& Myres, M.T. 1976. Declines in populations of peregrine falcons and their seabird prey at Langara Island, British Colombia. The Condor 78: 281293.

Nogales, M., Zonfrillo, B. \& Monaghan, P. 1995. Diets of adult and chick Herring Gulls Larus argentatus on Ailsa Craig, south-west Scotland. Seabird 17: 56-63.

Pagani-Nunez, E., Barnett, C.A., Gu, H. \& Goodale, E. 2016. The need for new categorizations of dietary specialism incorporating spatio-temporal availability of individual diet specialization. Journal of Zoology DOI: 10.1111/jzo.12364.

Paine, R.T., Wootton, J.T. \& Boersma, P.D. 1990. Direct and indirect effects of peregrine falcon predation on seabird abundance. The Auk 107: 1-9.

R Core Team. 2018. R: A language and environment for statistical computing. R Foundation for Statistical Computing, Vienna, Austria. https://www.Rproject.org/.

Ratcliffe, D.A. 1993. The Peregrine Falcon $2^{\text {nd }}$ Ed., T. \& A.D. Poyser, London.

Sargeant, B.L. 2007. Individual foraging specialization: niche width versus niche overlap. Oikos 116: 1431-1437.

Schoener, T.W. 1974. Resource partitioning in ecological communities. Science 185: 27-39.

Sutton, L.J. 2015a. Prey spectrum and foraging behaviour of coastal Peregrine Falcons Falco peregrinus in South Devon. Devon Birds 68:2, 3-12.

Sutton, L.J. 2015b. Population status of the Peregrine Falcon Falco peregrinus on Lundy. Lundy Field Society Annual Report 2014 64: 98-102.

Sutton, L.J. 2016. Status of the Peregrine Falcon Falco peregrinus on Lundy: Breeding ecology and prey spectrum. Journal of the Lundy Field Society 5: 7588. 
Sutton, L.J., Burrell, R A. \& Loram, S. (2017). Spatio-temporal trends in the predation of large gulls by peregrine falcons (Falco peregrinus) in an insular breeding population. Raptor Journal 11: 103-109.

Terraube, J., Guixe, D. \& Arroyo, B. 2014. Diet composition and foraging success in generalist predators: Are specialist individual's better foragers? Basic and Applied Ecology 15: 616-624.

Velarde, E. 1993. Predation of nesting larids by Peregrine Falcons at Rasa Island, Gulf of California, Mexico. The Condor 95: 706-708.

White, C.M., Cade, T.J. \& Enderson, J.H. 2013. Peregrine Falcons of the World, Lynx Edicions, Barcelona.

Whitfield, D.P., Reid, R., Haworth, P.F., Madders, M. Marquiss, M. Tingay, R. \& Fielding, A.H. 2009. Diet specificity is not associated with increased reproductive performance of Golden Eagles Aquila chrysaetos in Western Scotland. Ibis 151: 255-264.

Wiens, J.A. 1984. Resource systems, populations and communities. In: Price, P.W., Slobodchikoff, C.N. \& Gaud, W.S. (eds). A new ecology: Novel approaches to interactive systems. John Wiley \& Sons, New York.

Wright, S.J. 1980. Density compensation in island avifaunas. Oecologia 45: 385-389. 


\section{Appendix 1}

400 Table S1. Frequency and biomass of all prey species taken by five breeding pairs of Peregrine

401 Falcons on Lundy from April-August 2014-2017. Unit mass (g) taken from BTO (2016).

\begin{tabular}{|c|c|c|c|}
\hline Prey species & Frequency & Unit mass & Total biomass \\
\hline Mallard Anas platyrhynchos & $4(0.8)$ & 1210 & $4840(2.1)$ \\
\hline Eurasian Teal Anas crecca & $1(0.2)$ & 323 & $323(0.1)$ \\
\hline Manx Shearwater Puffinus puffinus & $246(47.3)$ & 383 & $94218(40.8)$ \\
\hline Common Kestrel Falco tinnunculus & $1(0.2)$ & 220 & $220(0.1)$ \\
\hline Merlin Falco columbarius & $1(0.2)$ & 202 & $202(0.09)$ \\
\hline Eurasian Woodcock Scolopax rusticola & $6(1.2)$ & 291 & $1746(0.8)$ \\
\hline Common Snipe Gallinago gallinago & $1(0.2)$ & 108 & $108(0.05)$ \\
\hline Eurasian Whimbrel Numensis phaeopus & $1(0.2)$ & 451 & $451(0.2)$ \\
\hline Razorbill Alca torda & $7(1.4)$ & 613 & $4291(1.9)$ \\
\hline Atlantic Puffin Fratercula arctica & $12(2.3)$ & 387 & $4644(2.0)$ \\
\hline Black-headed Gull Chroicocephalus ridibundus & $2(0.4)$ & 289 & $578(0.3)$ \\
\hline Lesser Black-backed Gull Larus fuscus & $3(0.6)$ & 785 & $2355(1.0)$ \\
\hline European Herring Gull Larus argentatus & $72(13.8)$ & 957 & $68904(29.8)$ \\
\hline Black-legged Kittiwake Rissa tridactyla & $7(1.4)$ & 368 & $2576(1.1)$ \\
\hline Domestic Pigeon Columba livia & $45(8.7)$ & 360 & $16200(7.0)$ \\
\hline Common Wood Pigeon Columba palumbus & $5(1.0)$ & 507 & $2535(1.1)$ \\
\hline Eurasian Collared Dove Streptopelia decaocto & $3(0.6)$ & 205 & $615(0.3)$ \\
\hline Common Cuckoo Cuculus canorus & $1(0.2)$ & 114 & $114(0.05)$ \\
\hline Carrion Crow Corvus corone & $3(0.6)$ & 509 & $1527(0.7)$ \\
\hline Eurasian Skylark Alauda arvensis & $11(2.1)$ & 36 & $396(0.2)$ \\
\hline Barn Swallow Hirundo rustica & $5(1.0)$ & 20 & $100(0.04)$ \\
\hline Long-tailed Tit Aegithalos caudatus & $1(0.2)$ & 8 & $8(0.01)$ \\
\hline Common Starling Sturnus vulgaris & $2(0.4)$ & 85 & $170(0.07)$ \\
\hline Common Blackbird Turdus merula & $1(0.2)$ & 102 & $102(0.04)$ \\
\hline Song Thrush Turdus philomelos & $4(0.8)$ & 75 & $300(0.1)$ \\
\hline Redwing Turdus iliacus & $2(0.4)$ & 66 & $132(0.06)$ \\
\hline Mistle Thrush Turdus viscivorus & $2(0.4)$ & 126 & $252(0.1)$ \\
\hline Common Chiffchaff Phylloscopus collybita & $2(0.4)$ & 8 & $16(0.01)$ \\
\hline Willow Warbler Phylloscopus trochilus & $1(0.2)$ & 9 & $9(0.01)$ \\
\hline European Robin Erithacus rubecula & $1(0.2)$ & 19 & $19(0.01)$ \\
\hline Northern Wheatear Oenanthe oenanthe & $4(0.8)$ & 28 & $112(0.05)$ \\
\hline House Sparrow Passer domesticus & $1(0.2)$ & 27 & $27(0.01)$ \\
\hline Meadow Pipit Anthus pratensis & $15(2.9)$ & 19 & $285(0.1)$ \\
\hline European Goldfinch Carduelis carduelis & $1(0.2)$ & 16 & $16(0.01)$ \\
\hline Common Linnet Carduelis cannabina & $4(0.8)$ & 19 & $76(0.03)$ \\
\hline Alcidae spp. & $1(0.2)$ & 500 & $500(0.2)$ \\
\hline Columbidae spp. & $1(0.2)$ & 357 & $357(0.2)$ \\
\hline Corvidae spp. & $2(0.4)$ & 376 & $752(0.3)$ \\
\hline Laridae spp. & $7(1.4)$ & 600 & $600(0.3)$ \\
\hline Unidentified Small Passerine & $15(2.9)$ & 45 & $675(0.3)$ \\
\hline European Rabbit Oryctolagus cuniculus & $16(3.1)$ & 1000 & $16000(6.9)$ \\
\hline Total & $520(100)$ & & $230951(100)$ \\
\hline
\end{tabular}

